\title{
Tree species distribution in tropical peatland forest along peat depth gradients: Baseline notes for peatland restoration
}

\author{
DWI ASTIANI ${ }^{1,2, \bullet}$, HANNA ARTUTI EKAMAWANTI ${ }^{1,2}$, WIWIK EKYASTUTI ${ }^{1,2}$, TRI WIDIASTUTI ${ }^{1}$, \\ GUSTI EVA TAVITA ${ }^{1}$, MURTI ANOM SUNTORO ${ }^{3}$ \\ ${ }^{1}$ Faculty of Forestry, Universitas Tanjungpura. J1. Prof. Hadari Nawawi, Pontianak 78124, West Kalimantan, Indonesia \\ Tel.: +62-561-765342, 583865, 732500, Fax.: +62-561-765342, `email: dwiastiani@ fahutan.untan.ac.id \\ ${ }^{2}$ Consortium of Tropical Peat Sciences, Kalimantan Universities Consortium. C.q. Universitas Tanjungpura. Pontianak 78124, West Kalimantan, \\ Indonesia \\ ${ }^{3}$ Forest Management Unit (KPH) Kayong Utara. Jl. Tanah Merah, Kayong Utara 78852, West Kalimantan, Indonesia
}

Manuscript received: 4 April 2021. Revision accepted: 7 June 2021.

\begin{abstract}
Astiani D, Ekamawanti HA, Ekyastuti W, Widiastuti T, Tavita GE, Suntoro MA. 2021. Tree species distribution in tropical peatland forest along peat depth gradients: Baseline notes for peatland restoration. Biodiversitas 22: 2571-2578. Tropical peatland forest is a unique and fragile ecosystem. It is composed of peat with a depth of $30 \mathrm{~cm}$ to $17 \mathrm{~m}$, and plays an essential role in maintaining an appropriate environment balance both as a water reservoir, sink and carbon storage, climate change, and support system for regional biodiversity, which is currently increasingly threatened. A study has been completed to examine peatland forest tree diversity in the gradients of peat depth found on the peatland fringe toward the center of the peat dome and the other side of the peatland perimeter in Sungai Besar peatland forest group in Ketapang West Kalimantan. Twenty-six plots measuring $20 \times 100 \mathrm{~m}$ were sampled to identify the tree species with a diameter above $5 \mathrm{~cm}$ along an $18 \mathrm{~km}$ transect length. The trees' assessment was accomplished using a systematic line plots method, where peat depth-plot repetitions were measured by producing 'fishbone' transects perpendicular to the main transect. Peat depths were assessed on plots measured. Results indicate that there were 82 tree species in overall peatland sites measured. It is found that peat depth has impacted tree species distribution on peatland. There was a shift of some tree species with peat depth changes. Along with peat depth range from 0.5 to $10 \mathrm{~m}$, some species were found to be abundant on a more extensive range of peat depth, such as perepat (Combretocarpus rotundatus), mentibu (Dactylocladus stenotachys), and bintangur (Calophyllum rigidum), while other were not. Some species were only found in shallow peat, and some were solely available in the deeper ones. It was found that peat depth could determine tree species distribution in peatland forests.
\end{abstract}

Keywords: Endangered species, peat depths, tropics, tree species richness, West Kalimantan

\section{INTRODUCTION}

Tropical peatlands provide significant contributions to environmental functions and human life. Peatland forest supports regional and global biodiversity (Yu et al. 2010), it supports large diversity of plants (Astiani 2016) and wildlife, some are endemic, rare, and endangered, especially birds, fish, mammals, and reptiles, and one of the most valuable habitats for the last remaining large populations of orangutan (Felton et al. 2003; MoroghBernard et al. 2014; Roucoux et al. 2017); store the most carbon (both above and below ground) per area among all forest ecosystems worldwide, thus have an important role in global carbon cycle (Limpen et al. 2008; Page et al. 2009; Astiani et al. 2017); important water catchment that provides drinking water and irrigations; act as buffer of salty water; and provide paleo-records of geochemical environmental information (Dommain et al. 2010; Chu et al. 2020). For local communities, forest provides resources such as fuel timber, wood barks, fruits, resins, medicines, aromatherapy, fuelwood, non-woody plant resources for food and agriculture, wildlife resources, horticultural resources, and energy resources (Posa et al. 2011; Astiani and Ripin 2016).
In the last two decades, tropical peat forests have experienced a lot of pressure both by natural and anthropological activities. Because of demographic, economic, and social changes, these forests continue to exercise significant pressure on forest cover and lands. The loss of natural forest in Southeast Asia region has continued at a rate of $1.4 \% \mathrm{y}^{-1}$, which was higher than the deforestation rates of Central America and the Caribbean $(1.2 \%)$ and South America $(0.5 \%)$, and currently, less than half (41.3-44.2\%) of the original forests of Southeast Asia remain (Sodhi et al. 2004). Peat swamps occur $\sim 12 \%$ of the SE Asian land area yet recently it accounts for $25 \%$ of current deforestation (Hooijer et al. 2006).

Large areas of tropical peatland have been: logged for wood products and supplying global demands; developed for either small-scale farming or large-scale agricultural plantation which involve extensive peatland drainage in Southeast Asia, (e.g., oil palm, corn, pineapple, and vegetables); and enormously exposed to fire damages. Across 1997-2006, Hooijer et al. (2006) estimated $1400 \mathrm{Mt}$ $\mathrm{y}^{-1}$ in $\mathrm{CO}_{2}$ emissions was affected by tropical peatland fire (i.e., from Southeast Asia) that are also closely related to peatland drainage, deforestation, and forest degradation. Those pressures cause decrease or loss of functions both 
for environmental and human-life support and result in severe impacts. The rapid land-use changes impact carbon sink role of tropical peatland increase their susceptibility to degradation and fire (Page et al. 2008) as well as biodiversity loss and other environmental damage and degradation (Astiani 2016). It is likely deforested and drained tropical peat swamps are a globally significant source of $\mathrm{CO}_{2}$ emissions (Hooijer et al. 2010; Astiani et al. 2018b; Sjögersten et al. 2018).

Kalimantan peatlands are one of the tropical peatland ecosystems in Indonesia, with extents $\sim 21$ Million Ha. Tropical peatlands usually formed dome in the center with several meters greater depth difference between the central and surrounding terrains. The middle part usually has lower nutrient availability and poorer drainage. It is known that there is a shift or gradient of vegetation along from peatland perimeter toward peatland center. Viewed from vegetation on peatland in Kalimantan and Sumatra, the floristic characters have only two main types of peatland: mixed swamp forest (in shallower peat) and 'padang', pole dominated, open forest more toward the center of the dome (Morley 2000). On the other hand, Morley (2000) described six phasic zones of peat swamp communities in Sarawak, Malaysia.

Recently, tropical peat swamp forests have received increasing pressures from anthropological disturbances (i.e. conversions, loggings, fires). The alteration in this ecosystem have resulted unbalanced natural systems and functions. Peatland degradation, edge effect, drainage ditches shift species composition on tropical peatland of West Kalimantan (Astiani 2016; Astiani et al. 2017; 2018a). The composition of natural vegetation helps us to understand the composition and diversity of each zone. One of pristine peatland areas in West Kalimantan recently is in Sungai Besar, Ketapang District. There is need for studying the natural vegetation zone in the area for future peatland restoration and revegetation of similar tropical peatlands. To search on the scientific knowledge of proper ecological information of tree species and a need for restoration, the objective of this study was to investigate the tree species distribution along with the path depth in the tropical peatland forest of Sungai Besar, Ketapang District.

\section{MATERIALS AND METHODS}

\section{Study site}

The study was conducted in the coastal-peatland-forest group of Pematang Gadung, Ketapang District, West Kalimantan Province, Indonesia, and focus on Sungai Besar Village, part of the large Pematang Gadung peatland area. It is located in $1^{\circ} 86{ }^{\prime} \mathrm{S}, 110^{\circ} 17^{\prime} \mathrm{E}$ to $1^{\circ} 97 \mathrm{~S}, 110^{\circ} 27^{\prime} \mathrm{E}$. The study site with the recent landcover condition is presented in Figure 1.

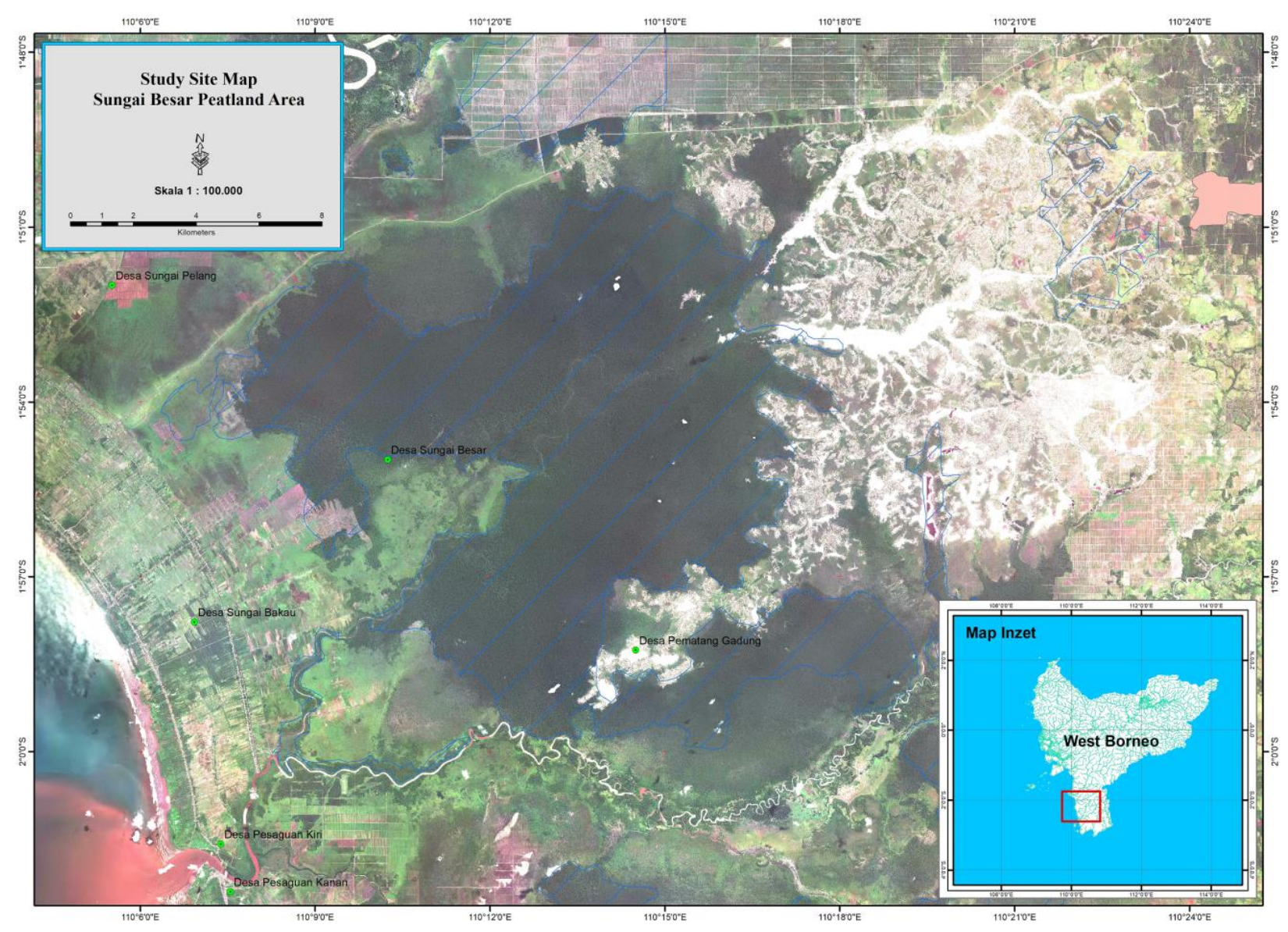

Figure 1. Map of Sungai Besar Peatland Forest in Ketapang District, West Kalimantan, Indonesia with recent landcover condition (Source: Kalimantan Spot 6/7 Imagery Mosaic Compilation 2013-2015) 


\section{Tree species assessment}

Above-ground survey was conducted using stratified sampling based on desk evaluation of differences in spectra of Spot 6/7 Image 5 (2015) and SRTM 90 m Resolution according to the land cover change or vegetation formations. Based on the map, the landcover or aboveground vegetation on peatland area was stratified into three types of land covers: Low degraded peat swamp forest; high degraded peatland forest; and open ex-burned area. The investigation resulted in all three landcover types were scattered around the peatland area, and therefore it was decided that the main transects were made across approximately through toward the center of peatland landscape.

The observation of tree species surveyed following main transect made from peatland fringe toward the center of the peat dome and continued to the other side of peatland perimeter. The assessment of trees was accomplished by using systematic line plots method, in which peat depth-plot repetitions were measured by producing 'fishbone' transects perpendicular to the main transect. For this study, twenty-nine of a $20 \times 100 \mathrm{~m}^{2}$ size plots were measured to identify the tree species with diameter above $5 \mathrm{~cm}$ along $18 \mathrm{~km}$ transect length. Within each plot, the assessment was executed following approaches as in Figure 2.

\section{Peat depth measurement}

Peat depths were assessed on each plot where the tree inventory was measured along the main transect. (Figure 3). Within the transect, each point of measurement was executed at the extent of $500 \mathrm{~m}$. However, when abrupt changes of peat depth were encountered, the peat depth was assessed in between the two points to check for the depth change gradation. The measurements were conducted manually using peat borer (Russian Peat Sampler) which could be utilized to take soil samples of peat cores as well. Along the peat transect surveyed, the peat depth distribution was in the ranges from $0.30 \mathrm{~m}$ to $10.25 \mathrm{~m}$

The soil samples were segmented into $20 \mathrm{~cm}$ each part, from soil surface to the peat depth until reach mineral soil underneath. All soil samples were packed and brought to Universitas Tanjungpura soil laboratory to further analyze soil C, soil moisture, and bulk density analysis.

\section{RESULTS AND DISCUSSION}

\section{General description of Sungai Besar Peatland forest of Ketapang District}

Peatland forest in Sungai Besar, is a coastal, ombrotrophic tropical peatland type. Peatland forest investigated may be described as the one that is still in good natural condition in a peat depth gradient of $25 \mathrm{~cm}$ to $10 \mathrm{~m}$. The forest structure showed peatland forest' normal dynamics, which still had complete structure from lower level as forest floor to the highest level above forest canopy. Some parts of the forest landscape were lowimpact logged by community surrounding the forest, as evident from few old, decayed tree stumps found along the survey tracks. Water table levels were mostly close to peat surface, and in some spots, it was inundated with excessive rainwater especially within a couple of days after rainfalls (Figure 4).

Along the main transect, the peat depth described in Figure 5, shallower peat was present in the western part perimeter of the landscape, while the deepest peat measuring $960 \mathrm{~cm}$ was within distance of $8000 \mathrm{~m}$ from the peat perimeter. Some abrupt changes within $1000 \mathrm{~m}$ distance from the transect were found indicating that the deepest peat was approximately $6500 \mathrm{~m}$ to $9500 \mathrm{~m}$ from peat edge.

Peat soil in the area was woody peat with intermediate to advanced development stages and can be classed into Hemist and Saprist. Soil bulk density ranged between 0.22 to $0.29 \mathrm{~g} \mathrm{~cm}^{-3}$. The survey recorded 82 tree species within the overall landscape. The dominant species found were nyatoh punyok (Palaquium leiocarpum), perepat (Combretocarpus rotundatus), mentibu (Dactylocladus stenotachys), and bintangur (Calophyllum rigidum).

\section{Tree species richness along the peat depths}

This study found that species richness decreased in the gradient of additional peat depth. There were shifts of tree species along the transect with perpendicular direction of peatland landscape, from the peatland perimeter across the middle of peatland landscape. The impact on peat depth on tree species richness was the deeper toward the dome shape of peat landscape where fewer species were recorded. It was noticed that significant reduction was on peat depth > $6 \mathrm{~m}$ (Figures 6 and 7) .

Figure 6 indicates the impacts of peat depth on tree species richness. More tree species inhabit at peat depth range of $0-6 \mathrm{~m}$, where a total of 78 tree species were found. At depth $>6 \mathrm{~m}$, species richness decreased drastically. On the deepest peat of this peatland landscape, only $<20$ tree species were found. The list of tree species and densities on each peat depth range is described in Table 1.

It was observed that species richness was decreasing toward deeper peat, especially at above $6 \mathrm{~m}$ depth. With similar trend, species density also tends to decrease toward deeper peat depth (Figure 8.A). Except in peat depth 0-2m, which is along the peatland perimeter and very adjacent to river and community settlement and higher risk to be encroached and exploited. The deeper peat depths from $\sim 4 \mathrm{~m}$ to 6,8 , and $10 \mathrm{~m}$ decreased tree density $35 \%, 48 \%$, and $50 \%$ consecutively. The fertility of peat soil is interaction between organisms and environmental conditions especially wetness, availability of oxygen, and pH (Rydin and Jeglum 2013). Decreasing species richness and density along the gradient of peat depth due to the decrease in soil fertility or nutrient availability and wetness of deeper peat was observed. Total $\mathrm{N}$ measured along the peat depth gradient supported these results (Figure 8.B). 


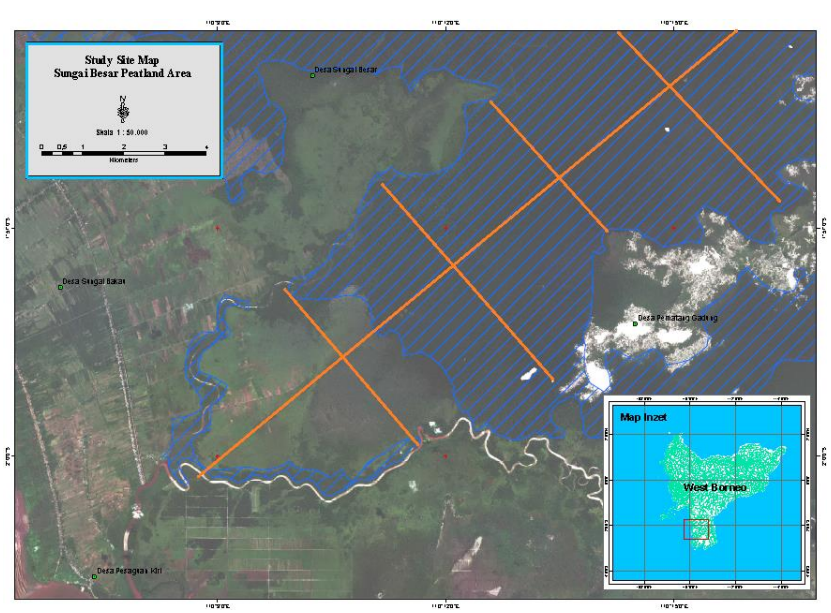

Figure 2. Fishbone transects produced for peat depth assessment

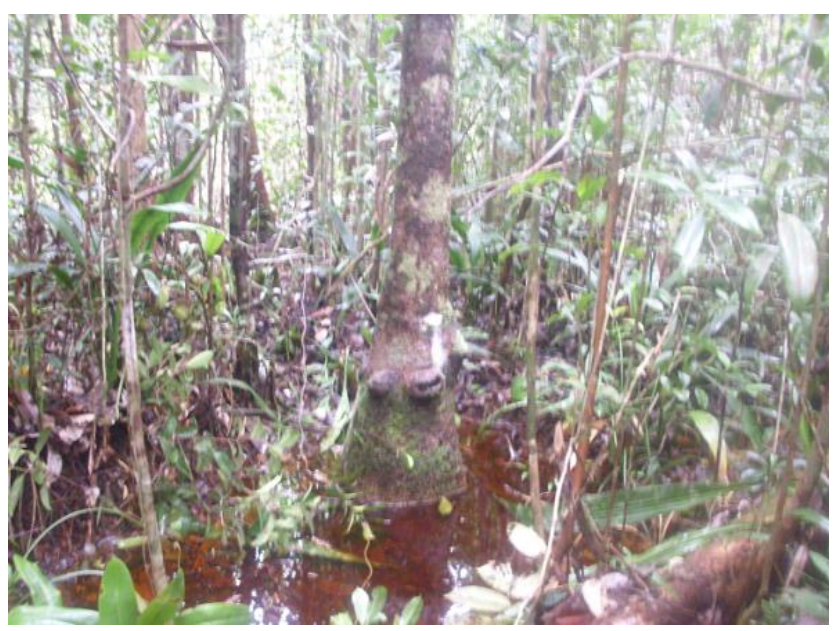

Figure 4. Inundated water on some spots of Sungai Besar peatland, Ketapang District, West Kalimantan, Indonesia

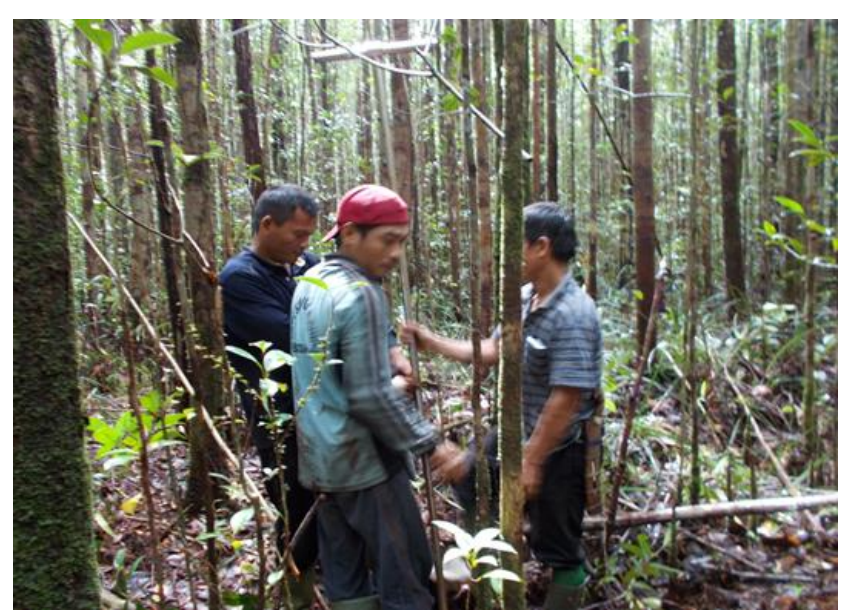

Figure 3. The peat-depth measurement activities along the main transect

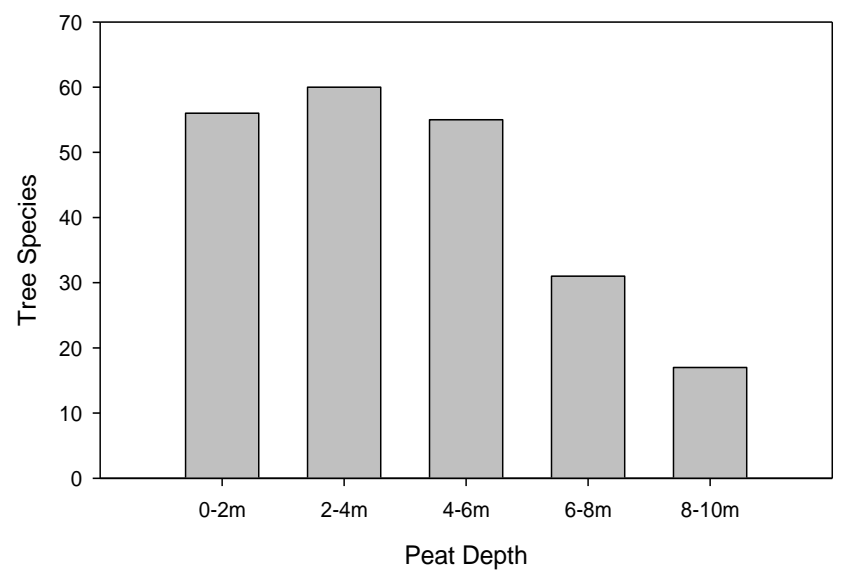

Figure 6. Tree species richness along with peat depth change within $0-10 \mathrm{~m}$ depth

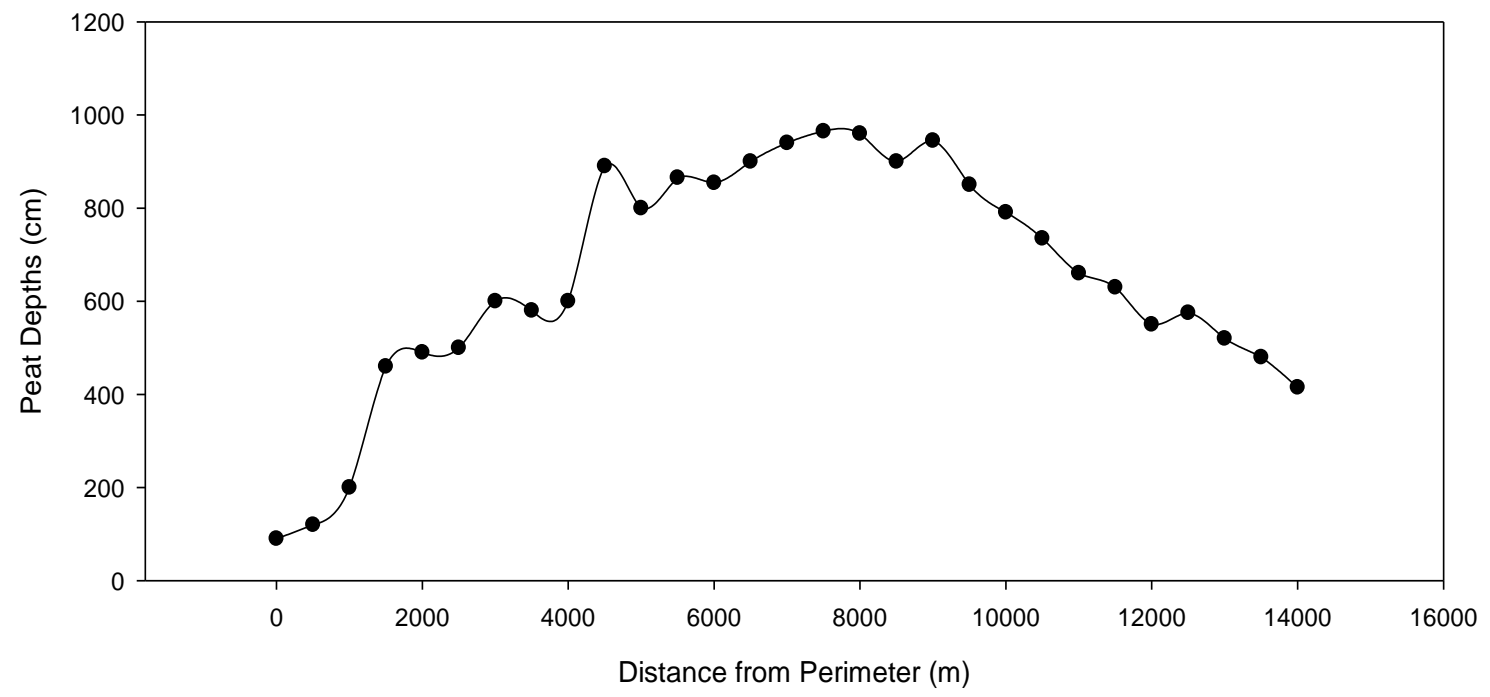

Figure 5. Peat depths gradient along the transect approximately in the middle of peat landscape 
Five species were only found in $0-4 \mathrm{~m}$ peat depth such as Engkaramek (Elaeocarpus sp.), Resak (Vatica pauciflora), Unang-unang (Maasia sumatrana), Jampang (Sandoricum koetjape), and Bintangor jangkar (Calophyllum hosei). Moreover, three species only inhabit on deeper peat 8-10m (i.e., Asam jungir, Keminting Tiong (Maasia glauca), and Keminting Hutan (Mezzettia sp.).

Some species adapted to all peat depth and distributed evenly. We found 8 species that were spread and suited to all peat depth gradient viz. kandis (Garcinia parvifolia), ramin (Gonystylus bancanus), ubah bentan (Parasetamom urophyllus), bintangor (Calophyllum rigidum), mentibu (Dactylocladus stenotachys), perepat (Combretocarpus rotundatus), nyatoh punjok (Palaquium leiocarpum), and nyatoh beras (Planchonella obovata). The findings on these species wide-range distribution should be beneficial to the choice of species recommendation for re-plantation programs or peatland restoration. It was found from other study of degraded peatland that some nyatoh species disappear from the site due to high forest degradation (Astiani 2018a).

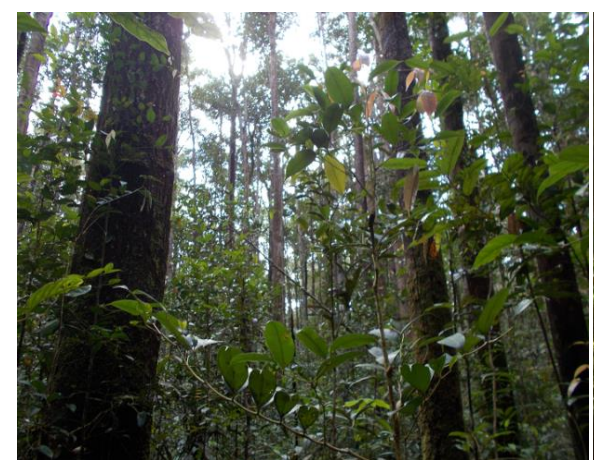

A

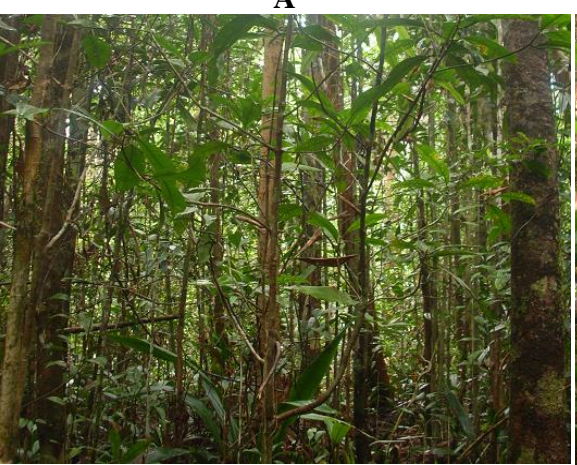

D

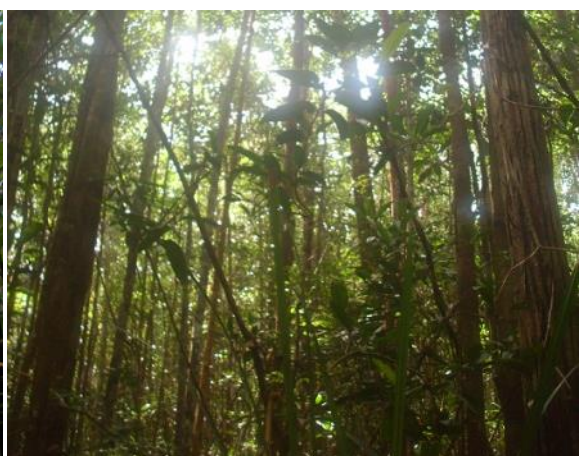

B

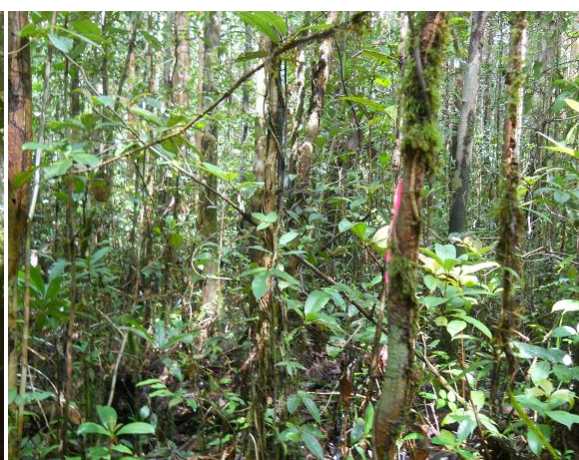

C

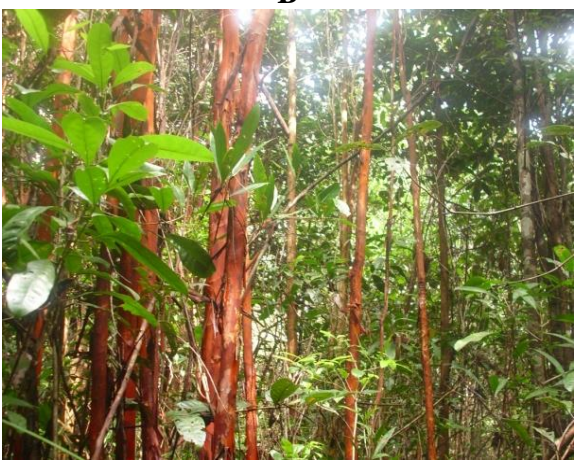

$\mathbf{E}$

Figure 7. Vertical view of tree species richness within A) 0-2m, B) 2-4m, C) 4-6m, D)6-8m, and E) 8-10m peat depths

Table 1. Tree species, abundance, and density found on each peat depth range of peatland forest of Sungai Besar, Ketapang District, West Kalimantan, Indonesia

\begin{tabular}{|c|c|c|c|c|c|c|c|}
\hline \multirow{2}{*}{ Local name } & \multirow{2}{*}{ Species } & \multirow{2}{*}{ Family } & \multicolumn{5}{|c|}{ Tree ha-1 } \\
\hline & & & $0-2 m$ & $2-4 m$ & 4-6m & 6-8m & 8-10m \\
\hline Asam jungir & unknown1 & & 0.0 & 0.0 & 0.0 & 0.0 & 1.7 \\
\hline Asam nyabong & Mangifera longipetiolata King & Anacardiaceae & 0.0 & 0.0 & 1.0 & 0.0 & 0.0 \\
\hline Asam nyabong & Santiria laevigata Blume forma glabrifolia (Engl.) H.J.Lam & Burseraceae & 0.0 & 0.0 & 1.0 & 0.0 & 0.0 \\
\hline Bedaru & Xanthophyllum ellipticum Korth. ex Miq. & Polygalaceae & 0.0 & 0.0 & 1.0 & 0.0 & 0.0 \\
\hline Bintangor & Calophyllum rigidum Miq. & Clusiaceae & 6.7 & 5.0 & 9.0 & 5.0 & 10.0 \\
\hline Bintangor jangkar & Calophyllum hosei Ridl & Clusiaceae & 5.0 & 3.8 & 0.0 & 0.0 & 0.0 \\
\hline Durian burung & Durio carinatus Mast. & Malvaceae & 0.0 & 1.3 & 1.0 & 0.0 & 0.0 \\
\hline Engkaramek & Elaeocarpus sp. & Elaeocarpaceae & 1.7 & 0.0 & 0.0 & 0.0 & 0.0 \\
\hline Gelam tikus & Syzygium incarnatum (Elmer) Merr. \& L.M.Perry & Myrtaceae & 1.7 & 2.5 & 1.0 & 2.0 & 0.0 \\
\hline Gerunggang & Cratoxylum glaucum Korth. & Hypericaceae & 11.7 & 2.5 & 4.0 & 2.0 & 0.0 \\
\hline Ilas & Neoscortechinia kingii (Hook.f.) Pax \& K.Hoffm. & Euphorbiaceae & 0.0 & 0.0 & 1.0 & 0.0 & 0.0 \\
\hline Jampang & Sandoricum koetjape (Burm.f.) Merr. & Meliaceae & 1.7 & 1.3 & 0.0 & 0.0 & 0.0 \\
\hline Japing 1 & Melicope lunu-ankenda (Gaertn.) T.G. Hartley & Rutaceae & 0.0 & 1.3 & 0.0 & 0.0 & 0.0 \\
\hline Jelutung & Dyera costulata (Miq.) Hook.f. & Apocynaceae & 5.0 & 17.5 & 13.0 & 10.0 & 1.7 \\
\hline Jonger & Tristaniopsis merguensis (Griff.) Peter G.Wilson \& J.T.Waterh. & Myrtaceae & 0.0 & 0.0 & 2.0 & 0.0 & 1.7 \\
\hline Kandis & Garcinia parvifolia (Miq.) Miq. & Clusiaceae & 8.3 & 7.5 & 7.0 & 1.0 & 5.0 \\
\hline Kayu cermai & unknown7 & - & 0.0 & 1.3 & 0.0 & 0.0 & 0.0 \\
\hline Kayu cin & Nageia wallichiana (C.Presl.) Kuntze & Podocarpaceae & 0.0 & 0.0 & 0.0 & 3.0 & 0.0 \\
\hline
\end{tabular}




\begin{tabular}{|c|c|c|c|c|c|c|c|}
\hline Kayu malam & Diospyros maingayi (Hiern.) Bakh. & Ebenaceae & 3.3 & 6.3 & 6.0 & 0.0 & 0.0 \\
\hline Kayu malam dk & Diospyros areolata King \& Gamble & Ebenaceae & 3.3 & 16.3 & 1.0 & 3.0 & 0.0 \\
\hline Kayu somah & unknown5 & - & 0.0 & 0.0 & 1.0 & 0.0 & 0.0 \\
\hline Kelampait & Tetractomia tetrandra Craib & Rutaceae & 0.0 & 2.5 & 0.0 & 2.0 & 0.0 \\
\hline Keminting & Mezzettia sp. & Annonaceae & 3.3 & 33.8 & 20.0 & 8.0 & 0.0 \\
\hline Keminting Hutan & Mezzettia sp. & Annonaceae & 0.0 & 0.0 & 0.0 & 0.0 & 1.7 \\
\hline Keminting tiong & Maasia glauca (Hassk.) Mols, Kessler \& Rogstad & Annonaceae & 0.0 & 0.0 & 1.0 & 0.0 & 0.0 \\
\hline Kempas & Koompassia malaccensis Benth. & Fabaceae & 0.0 & 3.8 & 3.0 & 0.0 & 0.0 \\
\hline Keranji & Parkia sumatrana Miq. & Fabaceae & 0.0 & 0.0 & 1.0 & 0.0 & 0.0 \\
\hline Kerawe babi & Mangifera swintonioides Kosterm. & Anacardiaceae & 5.0 & 17.5 & 11.0 & 4.0 & 0.0 \\
\hline Ketiong & Blumeodendron tokbrai (Blume) Kurz & Euphorbiaceae & 1.7 & 1.3 & 0.0 & 1.0 & 0.0 \\
\hline Kulam & unknown3 & - & 0.0 & 1.3 & 2.0 & 0.0 & 0.0 \\
\hline Kumpang & Knema cinerea Warb. & Myristicaceae & 0.0 & 1.3 & 0.0 & 0.0 & 0.0 \\
\hline Kumpang gym & Gymnacranthera contracta Warb. & Myristicaceae & 3.3 & 1.3 & 3.0 & 1.0 & 0.0 \\
\hline Manggeris & Koompasia malaccensis Benth. & Fabaceae & 0.0 & 6.3 & 0.0 & 0.0 & 0.0 \\
\hline Medang keladi & Litsea costalis var. nidularis (Gamble) $\mathrm{Ng}$ & Lauraceae & 6.7 & 13.8 & 10.0 & 2.0 & 0.0 \\
\hline Medang perawas & Litsea resinosa Blume & Lauraceae & 1.7 & 1.3 & 1.0 & 0.0 & 0.0 \\
\hline Medang sandak & Litsea turfosa Kosterm. & Lauraceae & 1.7 & 1.3 & 1.0 & 0.0 & 0.0 \\
\hline Mempasir daun kecil & Stemonurus secundiflorus Blume & Stemonuraceae & 5.0 & 2.5 & 5.0 & 1.0 & 0.0 \\
\hline Mempening & Quercus sp. & Fagaceae & 1.7 & 2.5 & 2.0 & 1.0 & 0.0 \\
\hline Mempisang & Mezzettia parviflora Becc. & Annonaceae & 0.0 & 0.0 & 1.0 & 0.0 & 0.0 \\
\hline Mendarahan & Gymnacranthera contracta Warb. & Myristicaceae & 0.0 & 2.5 & 0.0 & 0.0 & 0.0 \\
\hline mendarahan 1 & Knema kunstleri Warb. & Myristicaceae & 0.0 & 2.5 & 0.0 & 0.0 & 0.0 \\
\hline Mengkajang & Xylopia sp. & Annonaceae & 0.0 & 1.3 & 1.0 & 0.0 & 5.0 \\
\hline Mengkajang k2 & Blumeodendron tokbrai (Blume) Kurz & Euphorbiaceae & 0.0 & 15.0 & 0.0 & 0.0 & 5.0 \\
\hline Mengkapas & Alangium longiflorum Merr. & Cornaceae & 3.3 & 1.3 & 1.0 & 0.0 & 0.0 \\
\hline Mengkunyit & Neonauclea excelsa (Blume) Merr. & Rubiaceae & 0.0 & 0.0 & 1.0 & 0.0 & 0.0 \\
\hline Mengkunyit & unknown4 & - & 0.0 & 0.0 & 1.0 & 0.0 & 0.0 \\
\hline Mensire & Ilex cymosa Blume & Aquifoliaceae & 0.0 & 2.5 & 0.0 & 0.0 & 0.0 \\
\hline Mensubal & Elaeocarpus griffithii (Wight) A. Gray & Elaeocarpaceae & 3.3 & 1.3 & 3.0 & 0.0 & 0.0 \\
\hline Mentanang & unknown2 & - & 0.0 & 0.0 & 1.0 & 0.0 & 0.0 \\
\hline Menterong & Nauclea sp. & Rubiaceae & 0.0 & 2.5 & 0.0 & 0.0 & 0.0 \\
\hline Mentibu & Dactylocladus stenotachys Oliv. & Penaeaceae & 5.0 & 10.0 & 6.0 & 21.0 & 31.7 \\
\hline Meranti Batu & Shorea platycarpa F.Heim & Dipterocarpaceae & 0.0 & 0.0 & 4.0 & 1.0 & 5.0 \\
\hline Meranti bunga & Shorea uliginosa Foxw. & Dipterocarpaceae & 3.3 & 2.5 & 5.0 & 3.0 & 0.0 \\
\hline $\begin{array}{l}\text { Meranti sarang } \\
\text { elang (lilin) }\end{array}$ & Shorea teysmanniana Dyer ex Brandis & Dipterocarpaceae & 0.0 & 5.0 & 1.0 & 1.0 & 0.0 \\
\hline Nyatoh & Palaquium sp. & Sapotaceae & 1.7 & 2.5 & 2.0 & 1.0 & 10.0 \\
\hline Nyatoh Beras & Planchonella obovata (R.Br.) Pierre & Sapotaceae & 15.0 & 37.5 & 14.0 & 12.0 & 3.3 \\
\hline Nyatoh Punjok & Palaquium leiocarpum Boerl. & Sapotaceae & 10.0 & 62.5 & 40.0 & 51.0 & 51.7 \\
\hline Pangal & Elaeocarpus petiolatus (Jacq.) Wall & Elaeocarpaceae & 0.0 & 0.0 & 0.0 & 1.0 & 0.0 \\
\hline Parak api & Aglaia rubiginosa (Hiern) Pannell & Meliaceae & 0.0 & 0.0 & 1.0 & 0.0 & 0.0 \\
\hline Pelaik Pipit & Alstonia spatulata Blume & Apocynaceae & 0.0 & 0.0 & 1.0 & 0.0 & 0.0 \\
\hline Pelawan putih & Tristaniopsis merguensis (Griff.) Peter G.Wilson \& J.T.Waterh. & Myrtaceae & 3.3 & 1.3 & 3.0 & 2.0 & 0.0 \\
\hline $\begin{array}{l}\text { Pelawan } \\
\text { putih/todak }\end{array}$ & Tristaniopsis merguensis (Griff.) Peter G.Wilson \& J.T.Waterh. & Myrtaceae & 5.0 & 6.3 & 4.0 & 6.0 & 1.7 \\
\hline Perepat & Combretocarpus rotundatus (Miq.) Danser & Anisophylleaceae & 18.3 & 10.0 & 14.0 & 26.0 & 40.0 \\
\hline Petai hutan & Parkia singularis subsp. Borneensis H.C.Hopkins & Fabaceae & 0.0 & 1.3 & 1.0 & 0.0 & 3.3 \\
\hline Punak & Tetramerista glabra Miq. & Tetrameristaceae & 1.7 & 1.3 & 3.0 & 5.0 & 0.0 \\
\hline Rambutan hutan & Nephelium mangayi Hiem & Sapindaceae & 1.7 & 2.5 & 1.0 & 0.0 & 0.0 \\
\hline Ramin & Gonystylus bancanus (Miq.) Kurz & Thymelaeaceae & 0.0 & 5.0 & 4.0 & 3.0 & 6.7 \\
\hline Resak & Vatica pauciflora Blume & Dipterocarpaceae & 1.7 & 0.0 & 0.0 & 0.0 & 0.0 \\
\hline Semangkok & Scaphium macropodum (Miq.) Beumée ex K.Heyne & Malvaceae & 0.0 & 1.3 & 0.0 & 0.0 & 0.0 \\
\hline Sembabal & unknown6 & - & 0.0 & 1.3 & 0.0 & 0.0 & 0.0 \\
\hline Simpur laki & Dillenia pulchella (Jack) Gilg & Dilleniaceae & 1.7 & 2.5 & 4.0 & 0.0 & 0.0 \\
\hline Tenggayur k2 & unknown8 & - & 0.0 & 1.3 & 0.0 & 0.0 & 0.0 \\
\hline Terentang merah & Gluta wallichii (Hook.f.) Ding Hou & Anacardiaceae & 1.7 & 1.3 & 1.0 & 2.0 & 0.0 \\
\hline Terentang putih & Campnosperma squamatum Ridl. & Anacardiaceae & 3.3 & 2.5 & 0.0 & 0.0 & 0.0 \\
\hline Ubah & Syzygium sp. & Myrtaceae & 3.3 & 13.8 & 14.0 & 6.0 & 0.0 \\
\hline Ubah bentan & Parastemon urophyllus (Wall. ex A.DC.) A.DC. & Chrysobalanaceae & 5.0 & 1.3 & 4.0 & 7.0 & 6.7 \\
\hline Ubah gelam & Austrobuxus nitidus Miq. & Picrodendraceae & 0.0 & 1.3 & 0.0 & 0.0 & 0.0 \\
\hline Ubah jambu1 & Syzygium zollingerianum (Miq.) Amshoff & Myrtaceae & 0.0 & 1.3 & 0.0 & 0.0 & 0.0 \\
\hline Ubah jambu 2 & Syzygium zollingerianum (Miq.) Amshoff & Myrtaceae & 0.0 & 3.8 & 0.0 & 0.0 & 0.0 \\
\hline Ubah merah & Syzygium lineatum (DC.) Merr.\& L.M. Perry & Myrtaceae & 3.3 & 11.3 & 1.0 & 3.0 & 0.0 \\
\hline Unang-unang & Drepananthus biovulatus (Boerl.) Survesw. \& R.M.K.Saunders & Annonaceae & 0.0 & 3.8 & 2.0 & 0.0 & 0.0 \\
\hline Unang-unang dk & Maasia sumatrana (Miq.) Mols, Kessler \& Rogstad & Annonaceae & 1.7 & 1.3 & 0.0 & 0.0 & 0.0 \\
\hline Total density/ha & & & 171.8 & 381.8 & 248 & 197 & 191.9 \\
\hline
\end{tabular}




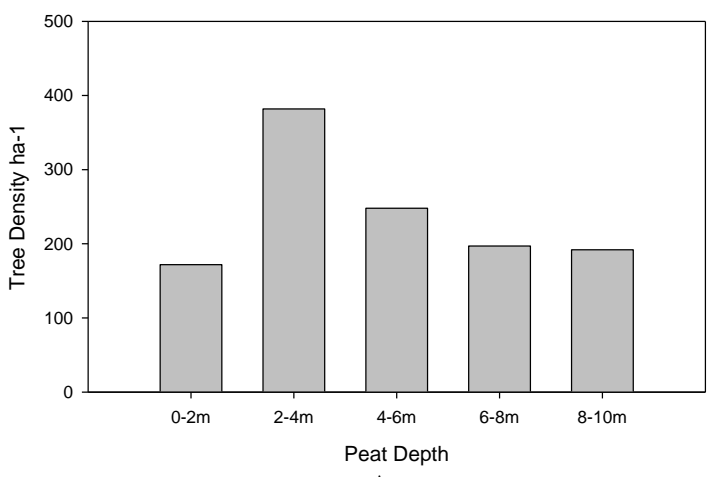

A

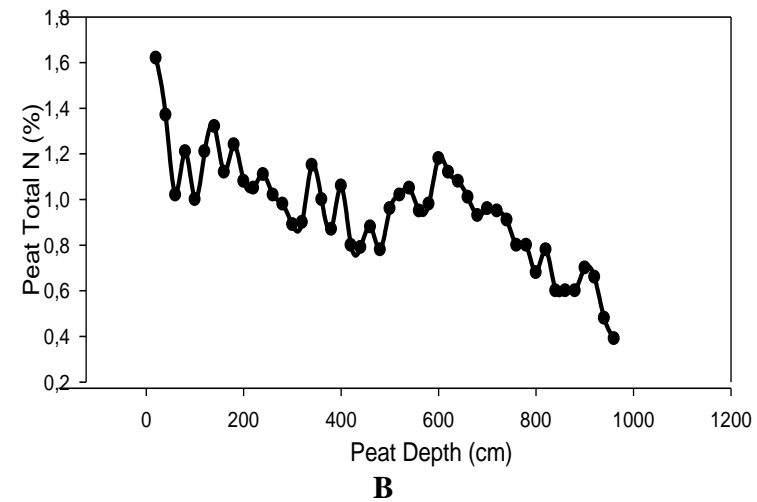

B

Figure 8. A. Tree density ha ${ }^{-1}$; B. Total $\mathrm{N}$ along the gradient of peat depths

In Sarawak, Malaysia (Morley 2000), based on their gradual change of stature and diversity toward the peat dome, can be described as follows: Phasic 1 had most complex structure and richest species with $40-45 \mathrm{~m}$ high, dominated by G. bancanus, D. stenotachys, Shorea spp; phasic 2 dominated by higher Shorea albida, (which was recorded only from Sarawak peatland forest) and Gonystylus bancanus, with $45-55$ high; phasic 3 is characterized and by tallest and most dominant $S$. albida that reach 50-60 m high zone; in phasic 4 has smaller bole display of $S$. albida and other species such as Litsea crassifolia with $30-40 \mathrm{~m}$, also characterized by poor understory forming, described as kerapah/kerangas; phasic 5 and 6 characterized by more impoverish, smaller poles size trees growth in deeper peat depth, reach $12 \mathrm{~m}$ maximum height, dominated by Tristaniopsis spp., $C$. rotundatus and L. crassifolia. In contrast to Morley (2000), the peatland forest in our study differs in several respect, it seems has no clear phasic zones from the peatland perimeter to the deeper peat of peat dome. Even though the information on tree stature was not available, some similar species such as D. stenotachys, $C$. rigidum, $P$. leiocarpum found and dominated at all zones with peat depth $0-10 \mathrm{~m}$, as well as $G$. bancanus, except in peat depth 0-2 G. bancanus was not found. Whereas in Sarawak those species mainly dominated around the peat perimeter. The prominent species in Sarawak, S. albida, was absence in our study area. In the first phasic along the peatland perimeter, the species richness was not as plenty as in Sarawak. However, the diminishing of species richness and abundance allegedly due to logging activities by communities around the peatland forest.

The phasic zones described above depend on the relationships among soil characters, peat depths, topography, and forest vegetation. In this regard dome shape of peat deposits and the association between the zonation of surface vegetation and water, nutrient availability, and increasing peat thickness and acidity were noted. . It is assumed that other than peat depth, the associated character of phasic zones mentioned was gradually/less shifted in the study area. Moreover, Bruenig (1996) suspected that differences in waterlogged conditions between central part and periphery of peat domes, which differ on their peat depth, is the determinant factor for vegetation phasic zone rather than peat nutrient contents.

Our investigation on some endangered species such as ramin ( $G$. bancanus), meranti sarang burung ( $S$. teysmanniana), resak (V. pauciflora) and kempas ( $K$. malaccensis), most had been exploited and utilized by local community to serve for their housing and incomegenerating in last 4-5 decades. These irresponsible activities on this ecosystem could threaten the extinction of rare tree species. It is suggested that coastal peatland areas that are inhabited by such endangered species should be conserved and managed for the species and ecosystem sustainability.

In conclusion peatland forest Sungai Besar of Ketapang District is composed of 82 tree species. The tree species richness tends to reduce toward the deeper depth. Different species or group of species have their peat-depth ranges assigned for their communities. However, no clear phasic zone was observed. A higher amount of tree species were found in peat depth 2-6 m than the shallower or, the deeper ones, and some species were found very limited on peat depth of $0-2 \mathrm{~m}$ or $8-10 \mathrm{~m}$. Ten species were primarily distributed on all peat depth range, and some were found to be abundant. It was demonstrated that some tree species in peatland forest inhabit their peat depth ranges. These findings could support tree species selection on forest enrichment and restoration programs, especially on degraded peatland forests, considering peat depth as the baseline to choose peatland species for replantation.

\section{ACKNOWLEDGEMENTS}

The authors would like to thank all contributors and private funders who have supported this study. A huge appreciation goes to Sungai Besar and Sungai Pelang villagers, Ketapang District, Indonesia, for their kindly involvement and support in the field works. 


\section{REFERENCES}

Astiani D. 2016. Tropical peatland tree species diversity altered by forest degradation. Biodiversitas 17 (1): 102-109. DOI: 10.13057/biodiv/d170115.

Astiani D, Ripin. 2016. The roles of community fruit garden (Tembawang) of Desa Cempedak, Kabupaten Sanggau on maintaining species diversity and standing biomass: an alternative effort on reducing carbon emission. Biodiversitas 17 (1): 359-365. DOI: $10.13057 /$ biodiv/d170148.

Astiani D, Mujiman, Rafiastanto A. 2017. Forest type diversity on carbon stocks: Cases of recent land cover conditions of tropical lowland, swamp, and peatland forests in West Kalimantan, Indonesia. Biodiversitas 18 (1): 137-144. DOI: 10.13057/biodiv/d180120

Astiani D, Curran LM, Mujiman, Ratnasari D, Salim R, Lisnawaty N. 2018a. Edge effects on biomass, growth, and tree diversity of degraded peatland in West Kalimantan Indonesia. Biodiversitas 19 (1): 272-278. DOI: 10.13057/biodiv/d190137.

Astiani D, Burhanuddin, Gusmayanti E, Widiastuti T, Taherzadeh MJ. 2018b. Enhancing water levels of degraded, bare, tropical peatland in West Kalimantan, Indonesia: Impacts on $\mathrm{CO}_{2}$ emission from soil respiration. Biodiversitas 19 (2): 522-527. DOI: 10.13057/biodiv/d190221.

Chu D, Grasby SE, Song H, Dal Corso J, Wang Y, Mather TA, et al. 2020. Ecological disturbance in tropical peatlands prior to marine Permian-Triassic mass extinction. Geology 48 (3): 288-292. DOI:10.1130/G46631.1.

Dommain R, Couwenberg J, Joosten H. 2010. Hydrological selfregulation of domed peatlands in south-east Asia and consequences for conservation and restoration. Mires and Peat 6 (5): 1-17.

Felton AM, Engström LM, Felton A. Knott CD. 2003. Orangutan population density, forest structure and fruit availability in handlogged and unlogged peat swamp forests in West Kalimantan, Indonesia. Biol Conserv 114 (1):91-101. DOI: 10.1016/S00063207(03)00013-2.

Hooijer A, Silvius M, Wösten H, Page S. 2006. PEAT-CO2, Assessmen of $\mathrm{CO}_{2}$ emissions from drained peatlands in SE Asia. Delft Hydraulics Report No. WL-Q_-3943, Delft Hydaulics, Netherlands.

Hooijer A, Page S, Canadell JG, Silvius M, Kwadijk J, Wësten H, Jauhiainen J. 2010. Current and future $\mathrm{CO}_{2}$ emissions from drained peatlands in Southeast Asia. Biogeosci 7: 1505-1514. DOI $10.5194 /$ bg-7-1505-2010
Limpens J, Berendse F, Blodau C, Canadell JG, Freeman C, Holden J, Roulet N, Rydin H, Schaepman-Strub G. 2008. Peatlands and the carbon cycle: from local processes to global implications - a synthesis. Biogeosci 5: 1475-1491. DOI: 10.5194/bg-5-1475-2008

Morrogh-Bernard HC, Husson SJ, Harsanto FA, Chivers DJ. 2014. Finescale habitat use by Orang-Utans in a disturbed peat swamp forest, Central Kalimantan, and implications for conservation management. Folia Primatol 85(3): 135-153. DOI: 10.1159/000358251.

Page S, Hoscilo A, Tansey K. 2008. Wildfire effects on tropical peatlands. Geophys Res Abs 10: 1-2.

Page S, Hoscilo A, Wösten H, Jauhiainen J, Silvius M, Rieley J, et al. 2009. Restoration ecology of lowland tropical peatlands in Southeast Asia: Current knowledge and future research directions. Ecosystems 12: 888-905. DOI: 10.1007/s10021-008-9216-2.

Posa MRC, Wijedasa LS, Corlett RT. 2011. Biodiversity and conservation of tropical peat swamp forests. BioScience 61(1): 49-57. 10.1525/bio.2011.61.1.10

Roucoux KH, Lawson IT, Baker TR, Del Castillo Torres D, Draper FC, Lähteenoja O, Gilmore MP, Honorio Coronado EN, Kelly TJ, Mitchard ETA, Vriesendorp CF. 2017. Threats to intact tropical peatlands and opportunities for their conservation. Conserv Biol 31 (6): 1283-1292. DOI: 10.1111/cobi.12925.

Rydin H, Jeglum JK. 2013. The biology of peatland. 2nd Ed. Oxford University Press, UK

Sodhi NS, Koh LP, Brook BW, Peter KLNG. 2004. Southeast Asian biodiversity: an impending disaster. Trends Ecol Evol 19 (12): 654660. DOI:10.1016/j.tree.2004.09.006.

Sjögersten S, Aplin P, Gauci V, Peacock M, Siegenthaler A, Turner BL. 2018. Temperature response of ex-situ greenhouse gas emissions from tropical peatlands: Interactions between forest type and peat moisture conditions. Geoderma 324: 47-55. DOI: 10.1016/j.geoderma.2018.02.029.

Morley RJ. 2000. Origin and Evolution of tropical rain forest. John Wiley and Sons Ltd., England

Bruenig EF. 1996. Conservation and Management of tropical rainforests: An integrated approach to sustainability, $1^{\text {st }}$ Edition. CAB International, Wallingford, Oxon, UK

Yu Z, Loisel J, Brosseau DP, Beilman DW, Hunt SJ. 2010. Global peatland dynamics since the Last Glacial Maximum. Geophys Res Lett 37: L13402, DOI: 10.1029/2010GL043584. 